\title{
SYNERGY IN SPACE - THE USE OF GIS TOOLS ON THE EXAMPLE OF PREMISES RECORDS IN THE LOD4 MODEL
}

\author{
Szczepan Budkowski ${ }^{1}$, Urszula Litwin² \\ ${ }^{1}$ GEO-Mapa Szczepan Budkowski mgr inż. Szczepan Budkowski 37-450 Stalowa Wola, Staszica 15b/19 \\ 2 Faculty of Environmental Engineering and Land Surveying, University of Agriculture of Krakow, \\ Al. Mickiewicza 24/28, 30-059 Kraków
}

\begin{abstract}
Aim of the paper

The aim of the paper is to answer a question regarding the possibility of using a modern system of real estate cadastre, which as an interoperable spatial database could carry out tasks in the field of public safety

Material and methods

In Poland there is a legal obligation to register history, which gives an opportunity to create a 3D + cadastre. This article presents a method of functioning of a multidimensional cadastre, with data applicable to various fields, e.g. security. The research method includes both an analysis of literature on land and building records as well as a use of GIS tools in network analysis. The research focused on a use of data regarding building interior in regard to public safety. It was realised using available GIS tools.
\end{abstract}

\begin{abstract}
Conclusions and results
The method of using graphical data related to premises (interior of buildings) presented in this paper extends beyond the currently performed cadastral functions and can be used, for example, to find an escape route. The task was realised with available GIS tools. In Poland, there is a legal obligation to register dates related to real estate, which gives the opportunity to create a 3D + cadastre. So far, there are no legal regulations pertaining to registration of geometrical data of premises and their presentation in a graphical part of a record. Full geometric and descriptive data on plots, buildings and premises can be used as an effective tool in space management: spatial planning, environmental protection, protection of natural resources, development of urbanization, as well as public safety
\end{abstract}

Keywords: multi-dimensional cadaster, GIS, synergy

\section{INTRODUCTION}

Real estate cadastre as a public register contains data on all plots of land, buildings and premises (Rozporządzenie Ministra Rozwoju Regionalnego i Budownictwa, 2001; Rozporządzenie Ministra Infrastruktury i Budownictwa, 2017). A multi-tasking cadastre should be considered in a context of general trend of cadastral systems development, for which comprehensive spatial information is a strategic resource (Bieda et al., 2015). Standardization requirements imposed by international agreements regarding the development of a global spatial data infrastructure give rise to new concepts of cadastre. (Enemark et al. 2014; Dawidowicz and Źróbek, 2018)

Technological development and computers have changed the existing concept of cadastre, which before

凶e-mail: szbudkowski@o2.pl 
was used only for taxes. However, currently, cadastre has many more functions, such as:

- Record function,

- Informative function,

- Control function,

- Tax function,

- Law-making function,

- Protective function,

- Integration function (Felcenloben, 2010).

A modern cadastral system should not only support demands for information of real estate (Felcenloben, 2011), spatial and environmental management, but also take into account broadly understood social needs. This paper aims at meeting one of these points by proving a hypothesis that it is possible to use a modern cadastral real estate system to perform public safety tasks. Contemporary development trends in the field of geospatial information underline these tendencies that take spatial phenomena and processes under wide consideration (Eckes, 2012). These relations are necessary to improve the quality of living and to ensure private and public safety. It seems important to pay more attention to logistic analyses aimed at prevention, as well as at maximising utilisation of available data.

As part of the conducted research, an existing literature on the subject was studied and a building model representing a multi-dimensional cadastre with a high level of detail (LoD4) was created. Such building was then used for network analyses.

Studies have shown the potential of cadastral systems for supporting public safety.

\section{APPLIED RESEARCH METHODS}

In the research an analysis of literature concerning land and building records as well as a use of GIS tools in network analyses was conducted.

The research was directed at examining a use of data regarding building's interior in respect to public safety.

\section{PROBLEMS}

Modern concepts of developing multi-dimensional cadastre should be considered in relation to initiatives undertaken within the current cadastral systems framework (Karabin, 2013). According to these theories, a cadastre plays a significant role, especially in real estate management process, providing a so-called 'sustainable development' (Enemark et al., 2005).

Originally, cadastral systems were introduced for financial reasons. Data was kept in records for calculations of property tax due. Land rights protection was another purpose for keeping such records. Development of information technologies and popularisation of computers enabled cadastral systems to become a base that can also be used in other field, such as economics or environmental protection (Urbański, 2012).

Cadastre, being a source of information on a given region, facilitates efficient land management (Litwin and Zawora, 2009). Land administration paradigm, consisting of spatial policy, spatial information infrastructure and real estate management functions, is crucial for sustainable development (Litwin and Szewczyk, 2012). This division was proposed in 2005 (Enemark et al., 2005).

To envision a cadastre (van Oosterom et al., 2006) of future, the rights and obligations as well as restrictions existing within cadastral system should be taken into account. Real estate cadastre needs to be uniform and consistent, so in effect blurring the difference between maps and records. A well-functioning cadastre should be run in an electronic form that enables its self-financing (Siejka et al., 2014, Siejka et al., 2014).

There are a number of factors that influence the need of introducing a multi-dimensional cadastre (Ronnberg and Hedmark, 2010). An increase in public awareness translates into growing importance of rights assigned to land, including situations where a 3D cadastre appears to be necessary, for example, increasing availability of drones, which may interfere with privacy (Stoter, 2004). An important factor in development of $3 \mathrm{D}$ cadastre is the possibility of reacting to various types of threats (Eckes, 2012). These can be related to rise of sea levels or pollution. Another step that can be made in the near future is the ability to analyse data and their visualization in real time and a possibility of forecasting various phenomena. The benefits of using a three-dimensional cadastral system can become an important argument for discussing the reorganization of cadastre structure (Litwin et al., 2017). In addition, progressing urbanization can make the current two-dimensional forms of plot record insufficient. It will be necessary to register three-dimensional objects (Ying et al., 2012). Advancing globalization also has an im- 
pact on propagating ideas on spatial objects registration (Doner et al., 2010).

Exactly on December 1, 2012, the international standard ISO 19152 'Geographic information - Land Administration Domain Model (LADM)' was published (INSPIRE, 2007). This standard was approved by the European Standardization Organization, and also on May 30, 2013, published in Poland. A standard is to enable setting up a uniform system of widely understood real estate administration operating within the European Community. Its tasks are following:

a) Defining a reference model containing basic components of real estate administration. it is important that a model includes objects located above land or water, as well as under the surface of land and water,

b) Providing a conceptual scheme containing four basic packages - such as: entities, administration, spatial elements, measurement package and spatial representation,

c) Providing terminology regarding real estate management in a domain of legal procedures and informal activities

d) Providing an outline for creating national and regional profiles

e) Ensuring possibility of combining data sets from various sources (D2.8.1.6 INSPIRE).

The Land Administration Domain Model (LADM), as a product is a conceptual scheme, written in the Uniform Language Modeling (ULM) notation, in accordance with the methodology described by the International Standardization Organization ISO 19100. The Land Administration Domain Model (LADM) (Lemmen, 2012) consists of four basic classes, which in turn are grouped into three packages and one subpackage (see: Fig.1).

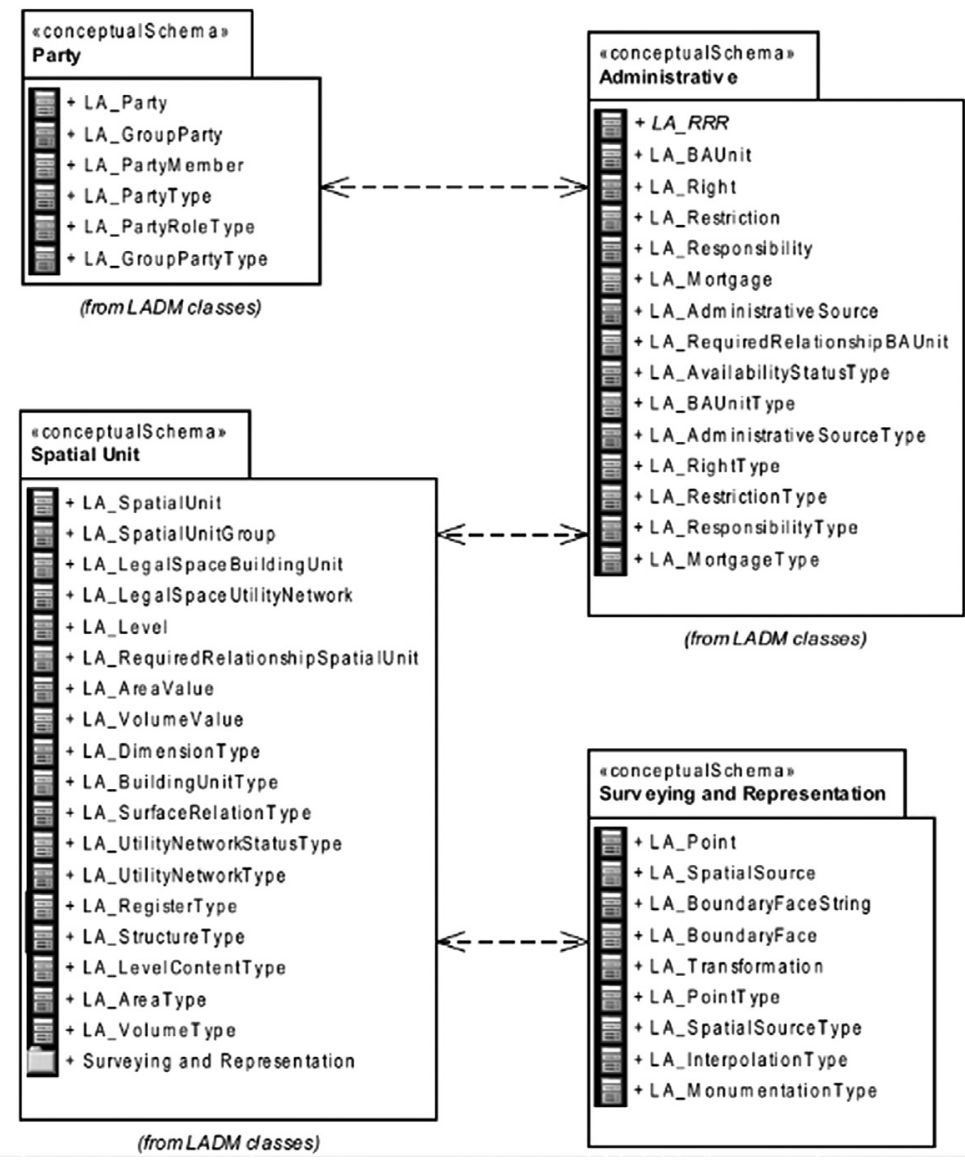

Fig.1. Basic ISO 19152 packages, including classes, source: ISO 19152 
The most important class from a point of view of this paper is that which refers to the $3 \mathrm{D}$ cadastre in the ISO 19152 standard signed as the LA_SpatialUnit class. Within the class there are spatial units, and each unit is a single or multiple spatial area (Rajabifard, 2014; Rajabifard et al., 2011). A spatial unit can be two-dimensional, three-dimensional or mixed. Its geometric representation consists of points that provide a basis for edges (D2.8.III.2 INSPIRE, 2012). They can be both regular and irregular (see: Fig.2).

\section{RESEARCH RESULTS}

The INSPIRE (INSPIRE, 2007) building specification assumes a possibility of using a different level of detail for specific tasks, thus four levels of detail can be distinguished (see: Fig.3): a) level LoD1, where a building or its part is represented by a right prism with vertical walls and a flat roof,

b) level LoD2, in which a building is presented generalized. It has a compact shape, but it reflects a geometry of objects - for example, a sloping roof;

c) level LoD3 - a building or its part is represented by a real shape, limited by flat figures with accurate information including entrances and window openings,

d) level LoD4 - data from the previous level are supplemented with data concerning space inside a building.

The need to create $3 \mathrm{D}$ representations of cities is strongly related to possibilities of performing multi-dimensional analyses, when there is a chance
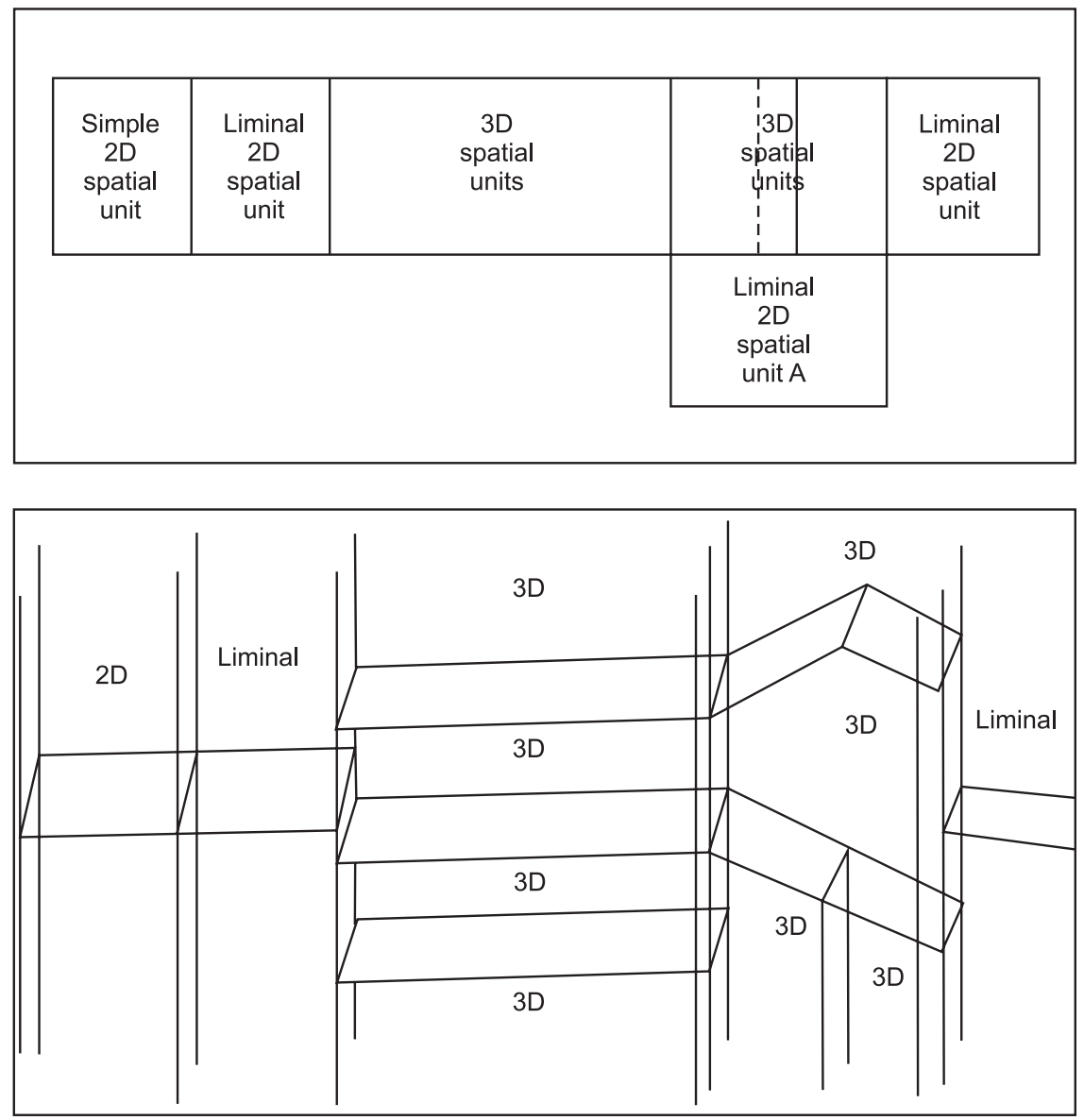

Fig. 2. Vertical and diagonal projection for mixed spatial representations, ISO 2012 

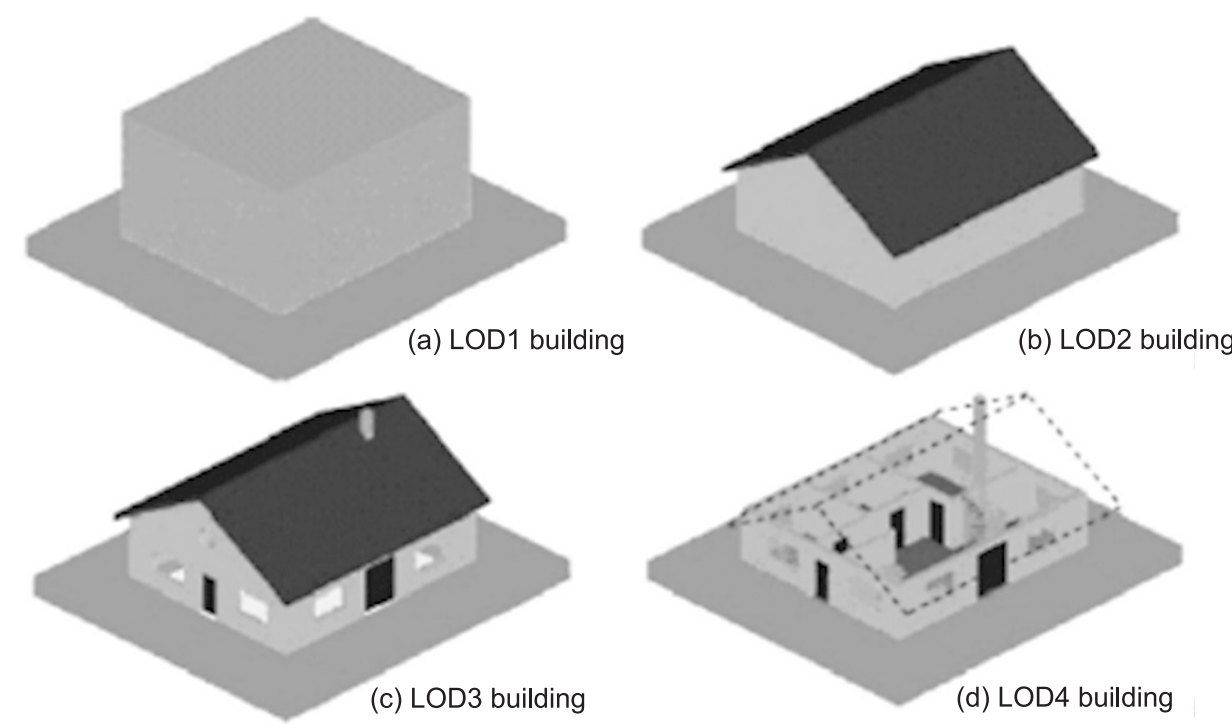

Fig. 3. Levels of building detail in City GML language, source: City GML 2013 specification

for full interpretation of urban space (van Oosterom, 2012; Doner et al., 2010). In an era of increasing demand for accurate cadastral information, analogically to SMART City, a term SMART Cadastre can be introduced. This term should be understood as transcendent and synergistic cadastre. Although a main purpose of a database is to determine real estate tax on grounds of its information, it can also be used for other purposes, which may indicate a certain 'added value' that does not result directly from the record's nature.

Assuming the possibility of creating a cadastral system (Shoshani et al., 2004) that implements a concept of synergy, a system with augmented reality (AR) created for investment cases, which is already used in everyday life, can be applied. For example, having three-dimensional data with a recorded history, an investor can acknowledge his rights to land with a scope of these rights in real time. A multi-dimensional cadastre can also be used for analysing indoor movement. Carefully constructed models can help in various situations, such as mass events. Monitoring pedestrian traffic will allow choosing shorter route to a specific place. The system can also provide help in case of emergency and can provide with an evacuation route, especially useful for people, who do not know a room well or are under stress.
The visualization was generated by available programs (Arc Gis, Arc Scene) that provide with models of buildings and network analysis (Budkowski, 2013).

Existing materials available on the program's producer's website were used for analyses. Rendered polygons required stratification and division into sectors, within which passages between rooms at the same level were specified. For creating next levels it was necessary to ensure that there are connections between them, for example staircases or lift shafts. Using the Arc Toolbox tools, symbols of doors, walls and stairs (see: Fig. 4) were inserted in earlier marked points on appropriate layers.

The next step was to deliver a network analysis within the created building. An initial assumption was that there is an emergency situation with a person in a corridor on the 3 rd floor of a building. The first analysis included a choice of any evacuation route (see: Fig. 5), while the following analysis adopted a situation with elevator failure. In both cases, the software managed to correctly perform a task with an evaluation of time required to pass a chosen route. The first route was designated considering an elevator - because it was meant to search for the shortest evacuation route. The second route had the same condition, but the difference was the elevator failure. The program therefore gave a longer route through a staircase (see: Fig.6). 


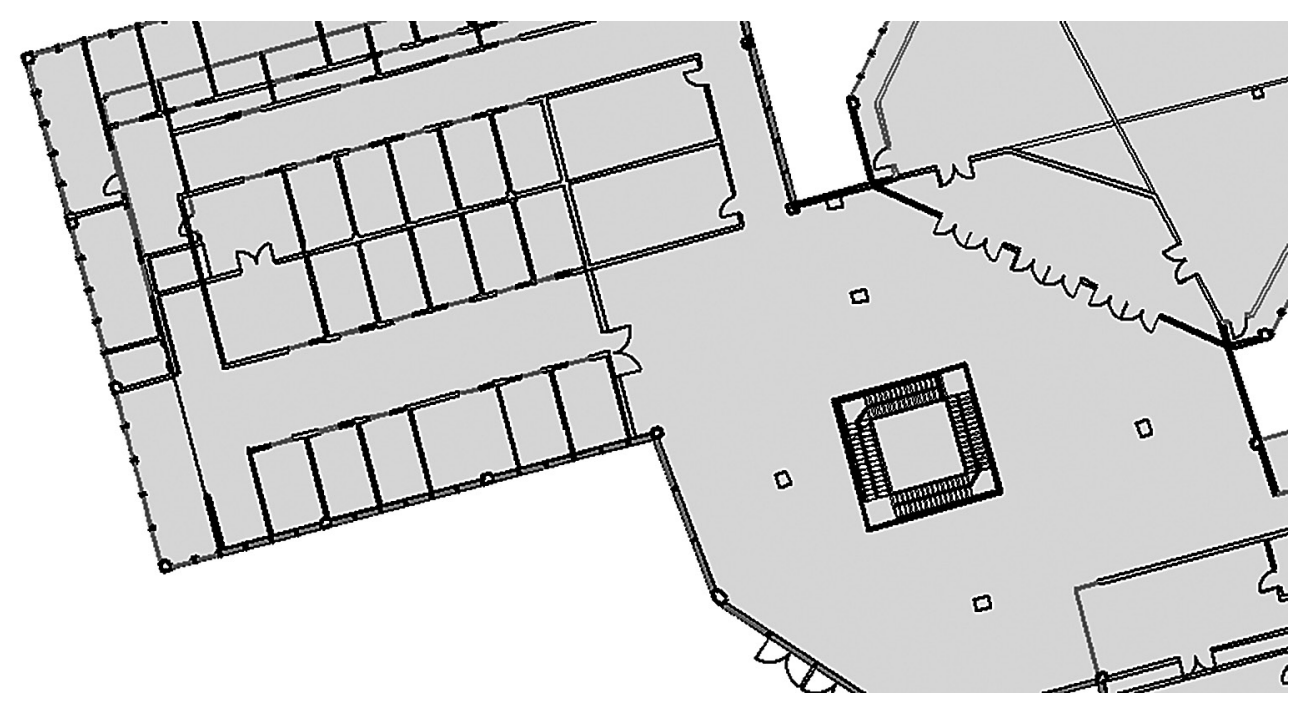

Fig. 4. Spatially created building, source: own study

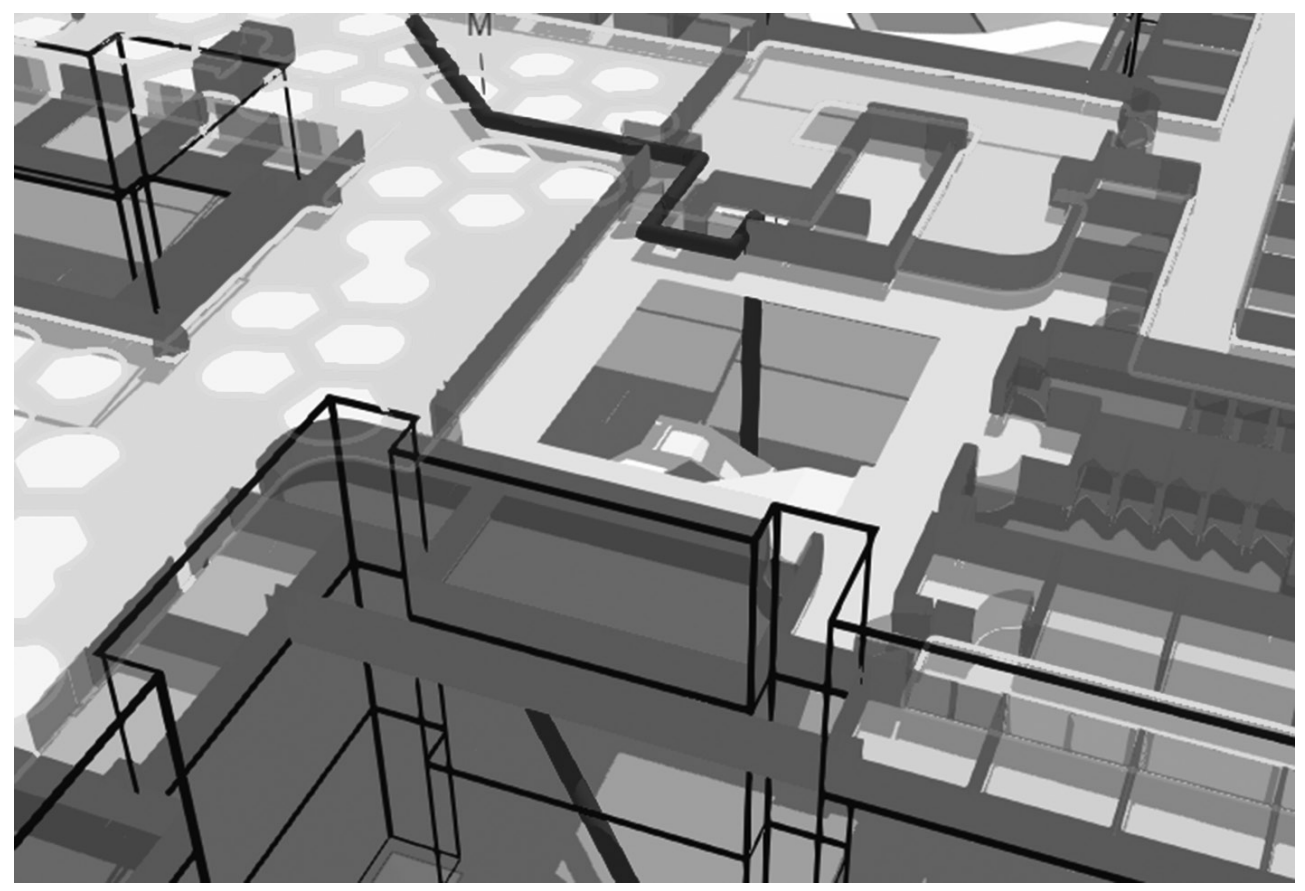

Fig. 5. The route covered by the elevator in 1 minute 49 seconds, source: own elaboration 


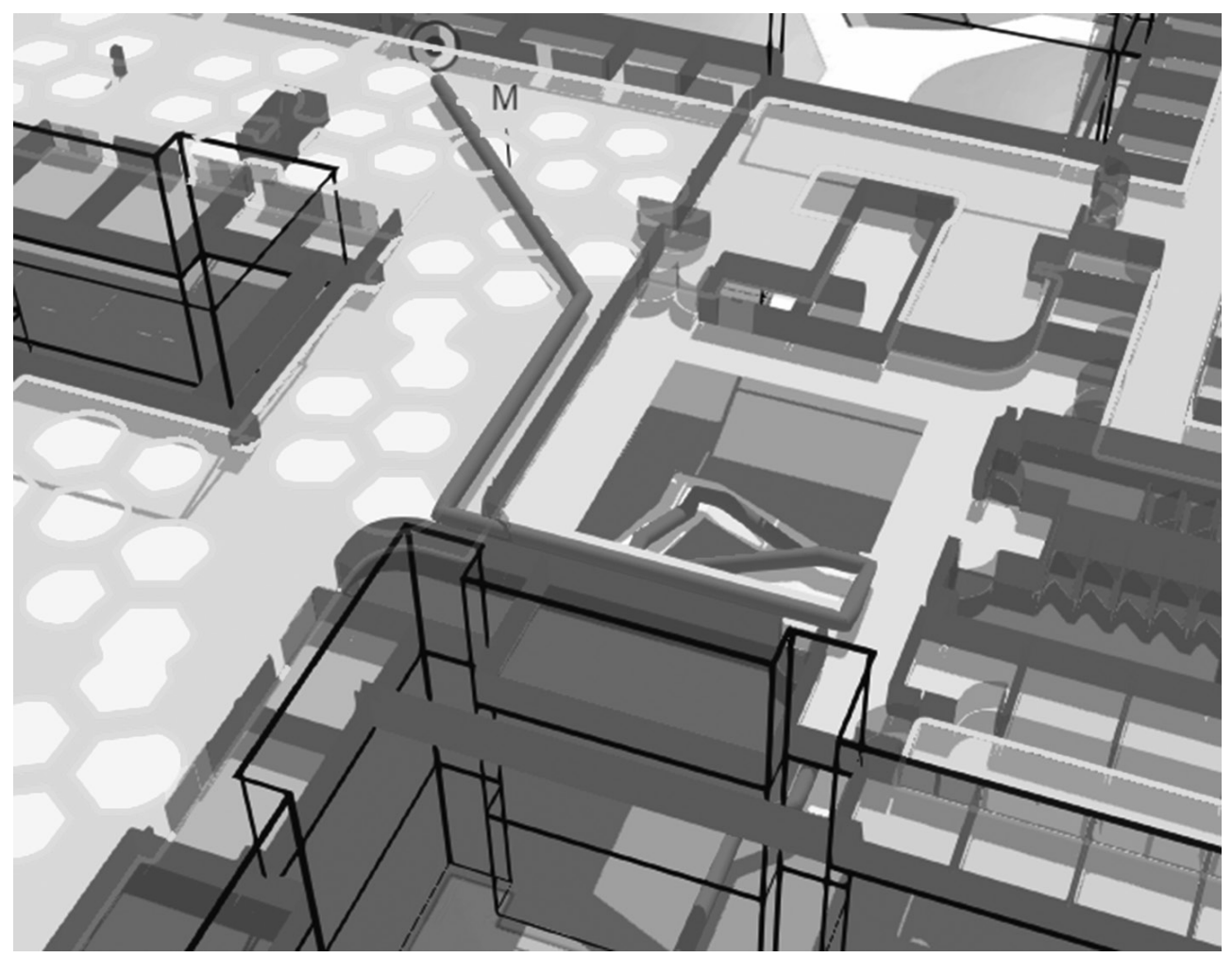

Fig. 6. Route covered with stairs in 2 minutes 15 seconds, source: own study

\section{SUMMARY - DISCUSSION OF RESULTS WITH LITERATURE}

Very advanced GIS software allows for complex building models, which enable analyses extending beyond initial application of a record like a real estate cadastre. The notion of constructing a multi-dimensional cadastre, as well as its multifaceted use, is confirmed in Polish and foreign publications. An introduction of multi-dimensional cadastral system proposed by Stoter (Stoter J.E., 2004) makes a cadastre acquire new functions and new possibilities. Among Polish scientists, a similar view belongs to Karabin (Karabin, 2013). These functions relate, i.a., to spatial planning, environmental protection, protection of natural resources, development of urbanization, as well as public security, as pointed out by Eckes (Eckes, 2012). This topic was also raised by a team of scientists (Enemark et al., 2004) arguing for flexibility in modern cadastre, which should focus on serving purposes, such as, ensuring security. Also Dawidowicz reckons the currently existing cadastral system should be modified into a multi-task cadastre with comprehensive spatial information (Dawidowicz and Źróbek, 2018).

Ideas presented in publications of above-mentioned scientific community correspond with the results of this research and confirm its hypothesis. However, the actual implementation of it is original.

With accurate information on cubature objects the location of premises inside facilities can be mapped precisely, and additionally existing bases enriched with new information. In Poland, only separated premises are disclosed in a record, but it is nowhere near full registration of an object as a 3D object (no graphic part). Dominating in countries of European Union trends indicate that over time premises are going to be recorded comprehensively (INSPIRE, 2007).

Solutions presented in this paper confirm the research statement that it is possible to use modern 


\section{system of real estate cadastre to perform tasks in public security.}

\section{CONCLUSIONS}

The method of using graphical data on premises (buildings' interior) presented in this paper extends beyond the currently performed cadastral functions and can be used, for example, for finding an escape route. The task was realised with the available GIS tools. In Poland, there is a legal obligation to register dates relevant to real estate, which gives an opportunity to create a cadastre $3 \mathrm{D}+$ time. So far, there are no legal regulations regarding keeping records of geometrical data of premises and presenting them graphically in a record. Full geometric and descriptive data on plots, buildings and premises can provide with an effective tool in space management: spatial planning, environmental protection, protection of natural resources, development of urbanization, as well as public safety.

Certainly, the subject matter requires further research in organizational and legal terms to ensure development of space management.

\section{REFERENCES}

Budkowski, S. (2013). Wykorzystanie zaawansowanych analiz sieciowych dla wyszukiwania lokalizacji hurtowni na terenie miasta San Francisco, praca inżynierska.

Bieda, A., Bydłosz, J., Dawid, L. Dawidowicz, A., Glanowska, M., Góźdź, K., Przewięźlikowska, A., Taratula, R., Źróbek, R. (2015). Kierunki rozwoju katastru nieruchomości Rzeszów, Rzeszów : Wyższa Szkoła Inżynieryjno-Ekonomiczna.

D2.8.III.2 (2012). INSPIRE Data Specification on Building-Draft Guidelines.

D2.8.1.6 (2009). INSPIRE Data Specification on Cadastral Parcels-Guidelines. INSPIRE Thematic Working Group Cadastral Parcels.

Dawidowicz, A., Źróbek, R. (2018). A methodological evaluation of the Polish cadastral system based on the global cadastral model. Land Use Policy 73, 59-72.

Doner, F., Thompson T., Stoter, J., Lemmen, Ch., Ploeger, H., Oosterom, P, . Zlatanova, S. (2010). 4D cadastres: First analysis of legal, organizational and technical impast-With a case study on utility networks, Land Use Policy, 27, 1068-1081.
Dyrektywa 2007/2/WE Parlamentu Europejskiego i Rady z dnia 14 marca 2007 r. ustanawiająca infrastrukturę informacji przestrzennej we Wspólnocie Europejskiej (INSPIRE).

Eckes, K. (2012). Analizy Logistyczne w GIS czasu rzeczywistego dla zapewnienia bezpieczeństwa imprez masowych, Roczniki Geomatyki.

Enemark, S., Bell, K. C., Lemmen, C. H. J., McLaren, R. (2014). Fit-for-purpose land administration. International Federation of Surveyors (FIG) and World Bank.

Enemark, S., Williamson, I.P., Wallace, J.. (2005) Buliding modern land markets in developer economiec Journal of Spatial Sciences, 50, 2.

Encyklopedia PWN (2017), Warszawa: PWN.

Felcenloben, D. (2009) Kataster nieruchomości rejestrem publicznym, Katowice: Gall.

Felcenloben, D. (2011). Criteria for assessing the quality of data and information collected and shared from the Real estate cadastre. Przegląd Geodezyjny 1, 11-17.

Karabin, M. (2013). Koncepcja modelowego ujęcia katastru 3D w Polsce, Prace Naukowe Politechniki Warszawskiej. Geodezja, 51.

Litwin, U. Zawora, P. (2009). Wartościowanie struktur przestrzennych za pomocą znormalizowanych wskaźników istotności terenu, Acta Scientarum Polonorum. Administratio Locorum, 82,15-27.

Litwin, U. Szewczyk, R. (2012). Morfologia działek przyczynkiem kształtowania krajobrazu, Infrastruktura i Ekologia Terenów Wiejskich, 2.

Litwin, U., Pluta, M., Mitka, B. (2017)., Improving the Perception in Urban Planning by 3D Modelling and 3D Visualization, vdf Hochschulerlag AG an der ETH Zurich.

Lemmen, Ch. (2012) A Domain Model for Land Administration NGC, Nederlandse Commissie voor Geodesie, Netherlands Geodetic Commission.

Rajabifard, A. (2014). 3D Cadastres and Beyond, Dubaj, 4th International Workshop on 3D Cadastres.

Rajabifard, A.; Bennet, R.; Moshen, K. (2011). Beyond Cadastre 2014, GIM-International (FIG Special), 25.

Ronnberg, K., Hedmark, I. (2010). The City Line in Stocholm, the longest Tyree dimensional propert unit in Sweden, FIG Congress 2010- Facing the ChallengesBulding the Capacity, Sydney, Australia, 11-16.

Rozporządzenie Ministra Rozwoju Regionalnego i Budownictwa z dnia 29 marca 2001 r. w sprawie ewidencji gruntów i budynków (Dz.U.2001 nr 38, poz. 454).

Rozporządzenie Ministra Infrastruktury i Budownictwa z dnia 14 listopada 2017 r. zmieniające rozporządzenie w sprawie warunków technicznych, jakim powinny 
odpowiadać budynki i ich usytuowanie (Dz.U.2017 poz. 2285).

Shoshani, U., Bnehamu, M., Goshen, E., Denekamp, S. Bar, R. (2004). Registration of Cadastral Spatial Right in Israel - a Research and Development Projects, Athens, Grece, FIG Working Week.

Siejka, M., Ślusarski, M. Zygmunt, M. (2014). 3D + time Cadastre, Warszawa: PAN.

Siejka, M., Ślusarski, M., Zygmunt, M. (2014). Multidimensional Cadastre implementation possibilities in Poland, Kraków, GLL, II, 2.

Stoter, J.E. (2014). 3D cadastre, TU Delft.

Urbański, J. (2012). GIS w badaniach przyrodniczych, Gdańsk: Wydawnictwo Uniwersytetu Gdańskiego van Oosterom, P., Ploeger, H., Stoter J., Thompson R., Leemen Ch. (2006). Aspects of a 4D Cadastre: a first exploration, Proceedings of XXIII FIG Congress.

van Oosterom P. (2012). 4D-Cadastral registration of rights, restrictions and eesponsobotites, Thrid International Engineering Systems Symposium, Delft Netherlands, Design and Governance in Engineering systems.

Ying, S., Guo, R., Li, L., He, B.(2012). „Application of 3D GIS to 3D Cadastre in Urban Environment" 3rd International Workshop on 3D Cadastres: Developments and Practices, 25-26.

\section{SYNERGIA W PRZESTRZENI - MODELOWE UJĘCIE KATASTRU NIERUCHOMOŚCI}

\section{ABSTRAKT}

\section{Cel pracy}

Celem publikacji jest zaprezentowanie poglądów dotyczących funkcjonowania katastru wielowymiarowego na świecie oraz możliwości wprowadzenia podobnego modelu w warunkach polskich.

\section{Materiał i metody}

W Polsce istnieje prawny obowiązek rejestracji dat związanych z nieruchomością, co daje możliwość stworzenia katastru 3D + czas. W niniejszym artykule zaprezentowano sposób funkcjonowania katastru wielowymiarowego, którego dane mogą być wykorzystywane w różnych dziedzinach. Zadanie zostało zrealizowane przy pomocy dostępnych narzędzi GIS.

\section{Wyniki i wnioski}

Zaprezentowany w niniejszym artykule sposób przejścia z katastru dwuwymiarowego na kataster 3D, którego dane są wykorzystywane w różnych dziedzinach, jest możliwy do realizacji. Zadanie zostało zrealizowane przy pomocy dostępnych narzędzi GIS. W Polsce istnieje prawny obowiązek rejestracji dat związanych z nieruchomością co daje możliwość stworzenia katastru 3D + czas. Póki co nie ma regulacji prawnych dotyczących rejestracji danych geometrycznych lokali i uwidaczniania ich w graficznej części ewidencji. Pełne dane geometryczne jak i opisowe dotyczące działek, budynków oraz lokali mogą być wykorzystywane jako skuteczne narzędzie w zarządzaniu przestrzenią: planowanie przestrzenne, ochrona środowiska, ochrona zasobów naturalnych, rozwój urbanizacji, a także bezpieczeństwo publiczne.

Słowa kluczowe: GIS, synergia, Kataster wielowymiarowy 